Çukurova Üniversitesi Mühendislik Mimarlık Fakültesi Dergisi, 32(1), ss. 9-21, Mart 2017

Çukurova University Journal of the Faculty of Engineering and Architecture, 32(1), pp. 9-21, March 2017

\title{
Kum Zemine Gömülü Çan Tipi Ankrajların Deneysel Çalışmalar ve Sayısal Analizler ile İncelenmesi
}

\author{
Ahmet DEMIR ${ }^{1}$, Bahadır OK ${ }^{* 2}$, Talha SARICI ${ }^{3}$, Mahmut EROĞLU $^{1}$ \\ ${ }^{1}$ Osmaniye Korkut Ata Üniversitesi, Mühendislik Fakültesi, İnşaat Mühendisliği Bölümü, \\ Osmaniye \\ ${ }^{2}$ Adana Bilim ve Teknoloji Üniversitesi, Mühendislik Fakültesi, İnşaat Mühendisliği Bölümü, \\ Adana \\ ${ }^{3}$ İnönü Üniversitesi, Mühendislik Fakültesi, Inşaat Mühendisliği Bölümü, Malatya
}

Geliş tarihi: 03.01.2017 Kabul tarihi: 14.03.2017

$\ddot{\mathbf{O} z}$

Temeller genellikle basınç yüklerine maruz kalmaktadır. Fakat rüzgar yükü vb. gibi yanal yüklere maruz kalan yüksek binalar, elektrik üretmek için kullanılan rüzgar tribünleri vb. gibi yapıların temelleri çekme yüklerine maruz kalmaktadır. Bu tip yüklere maruz yapıların temelleri tasarlanırken bu çekme kuvvetinin etkisini incelemek gerekmektedir. Bu çalışmada kum zemine gömülü çan tipi ankrajların çekme kapasitesi deneysel çalıșmalar ve numerik analizlerle incelenmiștir. Deneysel çalışmalarda ve sayısal analizlerde taban çapı 50, 100 ve $150 \mathrm{~mm}$ olan çan tipi ankrajlar kullanılmıştır. Çan tipi ankrajın eğimli yüzeyinin açısı, gömülme derinliği ve gömüldüğü kum zeminin sıkılığı gibi parametrelerin çekme kapasitesine etkisi araştırılmıştır. Ayrıca helisel ve dairesel ankrajların çekme kapasiteleri deneysel olarak bulunarak çan tipi ankrajların çekme kapasiteleri ile kıyaslanmıştır. Bu çalışmanın sonucunda görülmüştür ki, çekme kapasitesi ankraj açısının değişiminden çok fazla etkilenmemektedir ve çekme kapasitesi ankraj açısı arttıkça az bir miktar azalmaktadır. Ayrıca, çan tipi ankrajın çapı, gömülme derinliği ve gömüldüğü kumun rölatif sıkılığı arttıkça çekme kapasitesi artmaktadır.

Anahtar Kelimeler: Çan tipi ankraj, Çekme kapasitesi, Dairesel ankraj, Helisel ankraj, Kum zemin

\section{An Experimental and Numerical Investigation of Bell Type Anchor Plates Embedded in Sandy Soil}

\begin{abstract}
Foundations are often subjected by pressure loads. However, the foundations of structures such as highrise building, wind turbines for generating electricity etc. which is exposed to lateral loads such as wind load etc. are generally subjected to uplift loads. It is necessary to examine the effect of this uplift force when designing the foundation of such subjected loads. In this study, the uplift capacity of bell type anchors embedded in a sandy soil was investigated experimentally and numerically. Bell type anchors with base diameters of 50,100 and $150 \mathrm{~mm}$ were used. The effect of the parameters such as the angle of
\end{abstract}

"Sorumlu yazar (Corresponding author): Bahadır OK, bahadirok@adanabtu.edu.tr 
the sloping surface and embedding depth of the bell type anchor and relative density of the sand where the anchor was buried on the uplift capacity were investigated. Also, the uplift capacities of helical and circular anchors are found experimentally and compared with the uplift capacity of the bell type anchors. As a result of this study, the uplift capacity is not significantly affected by the change of the anchor angle and the uplift capacity decreases slightly as the anchor angle increases. In addition, the uplift capacity increases as the diameter and embedding depth of the bell type anchor, relative density of the sand where the anchor was buried increases.

Keywords: Bell type anchor, Uplift capacity, Circular anchor, Helical anchor, Sandy soil

\section{GİRIS}

Rüzgâr türbinleri, petrol platformları, haberleşme kuleleri, yüksek gerilim hatları, otoban ve demiryollarındaki işaret levhaları ve reklam panolarını taşıyan direkler gibi yapılar kendi ağrılıkları ile temellerinde basınç gerilmesi oluştururlar. Ancak çoğu durumda bu ve buna benzer yapıların temelleri çekme kuvvetlerine ve devirme momentlerine maruz kalmaktadırlar (Şekil 1). Bundan dolayı bu tarz yapıların temelleri çekme kapasitesi açısından da değerlendirilerek tasarlanmalıdır. Temellerin çekme kapasitelerini artırmak için geleneksel olarak yapılan temellerin boyutları artırılabilir. Fakat bu çözüm maliyet ve zaman açısından efektif değildir. $\mathrm{Bu}$ sorunun üstesinden gelmek, yapının stabilitesini artırmak için mühendisler ankraj temeli sistemleri kullanarak yeni bir inşaat metodu önermişlerdir.

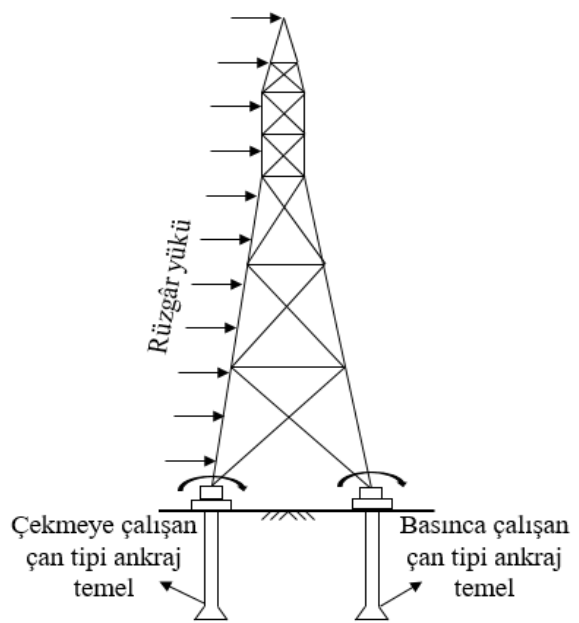

Şekil 1. Bir yüksek gerilim iletim hattı kulesinin temel sistemi örneği

\section{2. ÖNCEKİ CALISMALAR}

Yaklaşık olarak son 55 yılda, çok çeşitli ankraj temeli sistemleri geliştirilerek büyük değerlerdeki çekme kuvvetlerine karşı yapıların stabilitesi sağlanmaya çalışılmıştır. $\mathrm{Bu}$ konuda pek çok araştırmacı da konu ile ilgili çalışmalar gerçekleştirmişlerdir [1-12]. 1960 yılından bu yana temel sistemlerinin büyük değerlerdeki çekme kapasitesini karşılamak için dairesel, dikdörtgen, kare, helisel, çan tipi vb. ankraj temel sistemleri geliştirilmiştir. Ankraj temel sistemlerinden birisi olan çan tipi ankrajlar (ve ya genişletilmiş uçlu kazıklar da denebilir) büyük değerlerdeki çekme yüküne direnç sağlamada ekonomik bir temel türü olduğu ispatlanmıştır. Çan tipi ankrajlar hem basınç mukavemeti hem de çekme direnci sağlarlar [13]. Bir diğer ankraj temel sistemi olan helisel ankrajlar auger ekipmanına sahip herhangi bir kamyon ya da taşıyıcı aracılığıyla zemin içerisine inşa edilmektedirler [14]. En yaygın olarak kullanılan ankraj sistemi ise plaka tipi ankraj temellerdir [15]. Çapı ya da genişliği D, gömülme derinliği $\mathrm{H}$ olan bir sı̆̆ temelin nihai çekme kapasitesi olan $\mathrm{Q}_{\text {ult, }}$ yenilme yüzeyi boyunca zeminin sürtünme mukavemeti ile yenilme bölgesindeki zeminin ve temelin ağırlığının toplamından oluşmaktadır. Eğer ankraj temeli, bir çekme yüküne $\left(\mathrm{Q}_{\text {ult }}\right)$ maruz kalırsa, sı ̆̆ derinliklerde zemindeki yenilme yüzeyi Şekil 2'deki gibi gösterilebilir. Şekil 2'de görülen, zemin seviyesiyle yenilme yüzeyinin yatayla yaptığı $\alpha$ açısının değeri kumlu zeminlerde sıkılığa, killi zeminlerde ise kıvama bağlıdır [16]. 


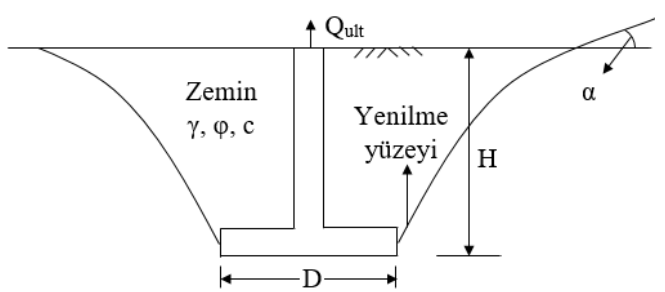

Şekil 2. Çekme yüküne maruz temel [16]

Ankraj sistemlerinin çekme kapasitesini temelin boyutu, gömülme derinliği, geometrisi ve temelin bulunduğu zeminin yoğunluğu önemli ölçüde etkilemektedir. Eğer arzu edilen çekme kapasitesi elde edilemez ise bu durumda temelin boyutu, gömülme derinliği ve bulunduğu zeminin yoğunluğu parametrelerinden birinin ve birkaçının artırılması yoluna gidilebilir [17]. Ankraj sayısını artırmakta çekme kapasitesine artırmada bir çözüm olabilir [18]. Dickin ve Laman [19] kum zeminde $1 \mathrm{~m}$ genişlikteki şerit ankrajın çekme dayanımını belirlemek için santrifüj deneyleri gerçekleştirmişlerdir. Bu deneyleri Plaxis paket programında modelleyerek şerit ankrajların çekme kapasitelerini incelemişlerdir. Kum zeminin sıkılığının ve ankrajın gömülme oranının çekme kapasitesini etkilediğini, sıkılık ve gömülme derinliği arttıkça çekme kapasitesinin arttığını görmüşlerdir. Deneysel çalışmalardan elde ettikleri sonuçları, teorik çalışmaları ve Plaxis analizlerini kıyaslamışlar ve değerlerin bir biri ile uyumlu olduğunu belirtmişlerdir. Ayrıca kum zemin içindeki ankrajın çekme davranışını modellemek için Plaxis'teki pekleşen zemin modelini (hardening soil model) kullanmanın iyi sonuçlar verdiğini görmüşlerdir. Ghaly ve arkadaşları [21] helisel ankraj plakalarının çekme kapasitelerini teorik ve deneysel olarak belirlemişlerdir. Deneysel çalışmalarını kumlu bir zemin tabakası oluşturarak gerçekleştirmişlerdir. Deneysel çalışmalarında sıkı, orta sıkı ve gevşek olmak üzere üç farklı sıkılıkta kum zemin kullanmışlardır. Kumun içsel sürtünme açısı ve gömülme derinliği ile yenilme modeli arasındaki ilişkiyi belirlemeye çalışmışlardır. Ilamparuthi ve arkadaşları [22] dairesel ankraj plakalarının çekme davranışını incelemek için nispeten büyük ölçekli deneysel çalışmalar gerçekleştirmişlerdir. 100 ile
$400 \mathrm{~mm}$ arasında değişen çaplarda dairesel ankrajlar kullanmışlardır. Deneyleri sıkı, orta sıkı ve gevşek kum zeminlerde yapmışlardır. Çekme kapasitesinin ankraj çapından, gömülme oranından ve kumun yoğunluğundan oldukça etkilendiğini söylemişlerdir. Kritik gömme oranını belirlemek için alternatif yöntemler belirlemişlerdir ve sırasıyla gevşek, orta sıkı ve sıkı kum için 4,8, 5,9 ve 6,8 değerlerini önermişlerdir. Bir temelin sığ durumdan derin duruma geçtiği andaki gömülme oranına, kritik gömülme oranı denilir. Das [16] ise kritik gömülme oranını, kumlarda 3-11 arasında, suya doygun kilde ise 3-7 arasında olduğunu belirtmişlerdir. Çekme yüklerine maruz bir temelde, eğer zemindeki yenilme yüzeyi zemin yüzeyine kadar uzuyorsa, buna sı̆̆ durum denilir. Daha büyük gömülme değerlerinde, yenilme temel etrafinda oluşabilir ve yenilme yüzeyi zemin yüzeyine kadar uzamayabilir. $\mathrm{Bu}$ ise derin durum olarak adlandırılırlar. Ayrica, geoteknik mühendisliği alanında donatı olarak kullanımı giderek yaygınlaşan geosentetik ürünler çekme kapasitesini artırmada bir alternatif olarak kullanılabilir. $\mathrm{Bu}$ durumu ortaya koyan ilk araştırmacılardan biri olan Subbarao ve arkadaşları [8] polipropilen şeritlerin dairesel ve çan tipi ankrajların çekme kapasitelerini arttırdığını belirtmiştir. Krishnaswamy ve Parashar [22] doğrudan ankrajın üst yüzüne oturan tek sıra geokomposit donatının diğer düzenlemelere göre daha fazla çekme kapasitesini artırdığını söylemişlerdir. Ilamparuthi ve Dickin [11] çan tipi ankrajlar üzerinde laboratuvarda çekme deneyleri yapmışlar ve çan kazıkların kopma faktörlerini araştırmışlardır. Değişik geometrilerde ve kum sıkılıklarında deneyler yapmışlardır. Ayrıca çan tipi ankrajın etrafina geogridleri bir hücre oluşturacak biçimde yerleştirerek bunun çekme kapasitesini nasıl etkilediğini incelemişlerdir. Deneysel kopma faktörleri ankraj temeller için önerilen mevcut bazı teorilerle karşılaştırmışlardır ve sonuçların uyumlu olduğunu belirtmişlerdir. Geogrid hücrenin çekme kapasitesini önemli ölçüde artırdığını söylemişlerdir.

Literatür araştırmalarından, hem geogrid ile güçlendirilmiş için hem de güçlendirilmemiş çan 
tipi ankrajların çekme kapasitesi üzerine yapılan çalışmaların oldukça sınırlı olduğu görülmüştür. $\mathrm{Bu}$ çalışmada, çan tipi ankrajların çekme kapasiteleri deneysel çalışmalarla ve sayısal analizler ile belirlenmiştir. Çan tipi ankrajların çekme davranışları belirlendikten sonra dairesel ve helisel ankrajlarınki ile kıyaslanmıştır. Çan açısı $(\alpha)$, taban çapı (D), gömülme oranı (H/D, $\mathrm{H}=$ gömülme miktarı), kumun sıkılığı $\left(\mathrm{D}_{\mathrm{r}}\right)$ gibi parametreler deneysel olarak incelenmiştir. Sayısal analizlerin gerçekleştirilmesi için kullanılan Plaxis paket programı ile yapılan deneysel çalışmalar modellenerek modelin geçerliliği ortaya konmuştur. Ayrıca deneysel çalışmalardan ve sayısal analizlerden elde edilen sonuçları daha genel bir şekilde ifade edebilmek ve literatürdeki çalışmalar ile kıyaslamak için boyutsuz bir parametre olan kopma faktörü $\left(\mathrm{F}_{\mathrm{q}}\right)$ kullanılmıştır.

\section{MATERYAL VE METOT}

\subsection{Deneysel Çalışma}

\subsubsection{Deney Düzeneği ve Yükleme Sistemi}

Deneysel çalışmalar Osmaniye Korkut Ata Üniversitesi İnşaat Mühendisliği Bölümü Geoteknik Laboratuvarındaki mevcut deney düzeneğinde gerçekleştirilmiştir. Deneysel çalışmalar kum zemin içerisine gömülü rijit model ankrajlara çekme kuvvetleri uygulanması suretiyle gerçekleştirilmiştir. Deney düzeneğinde model ankrajın çekme direncini ölçmek için yük hücresi, model ankrajı çekerken oluşan düşey deplasmanı ölçmek için deplasman ölçerler elde edilen yük ve deplasman verilerini kayıt etmek içinse veri toplama ünitesi kullanılmıştır.

Deneylerde kum yatağı oluşturmak için et kalınlığı $12 \mathrm{~mm}$, çap1 ve yüksekliği $600 \mathrm{~mm}$ olan çelik malzemeden yapılmış dairesel bir rijit çelik tank kullanılmıştır. Çan tipi, dairesel ve helisel olmak üzere üç farklı rijit model ankraj kullanılmıştır. 50, 100 ve $150 \mathrm{~mm}$ olmak üzere üç farklı çapta çan tipi ankraj, 50 ve $100 \mathrm{~mm}$ olmak üzere iki farklı çapta dairesel ankraj, $50 \mathrm{~mm}$ olmak üzere tek farklı çapta helisel ankraj kullanılmıştır. Model ankrajların şematik çizimi Şekil 3 'te görüldüğü gibidir.
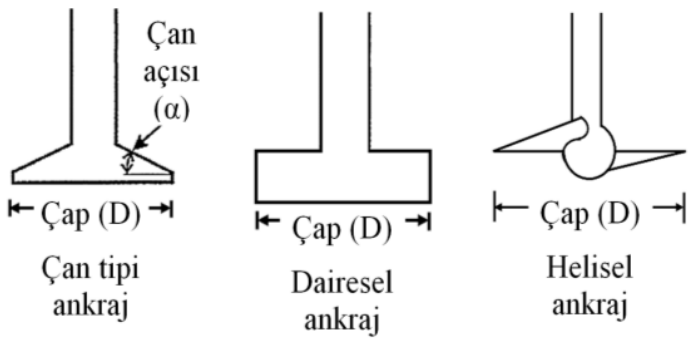

Şekil 3. Deneylerde kullanılan model ankrajlar [23]

Model ankrajlar, $20 \mathrm{~mm}$ çapında rijit bir çubuğa sabitlenmiştir. Çekme kuvveti çubuk vasıtası ile model ankraja iletileceğinden oluşturulan tüm bu sistemin rijit olmasina ve deney sirasinda bütünlüğünü koruyup yatay yönde hareket etmemesine dikkat edilmiştir. Yükleme çerçevesi rijit I profillerden imal edilmiştir. Yükleme motoru, kontrol paneli yardımı ile ilerleme hızı sabit tutularak çekme kuvveti oluşturulmasını sağlamıştır. Şekil 4'te deney düzeneği ve yükleme sistemine ait şematik çizim görülmektedir.

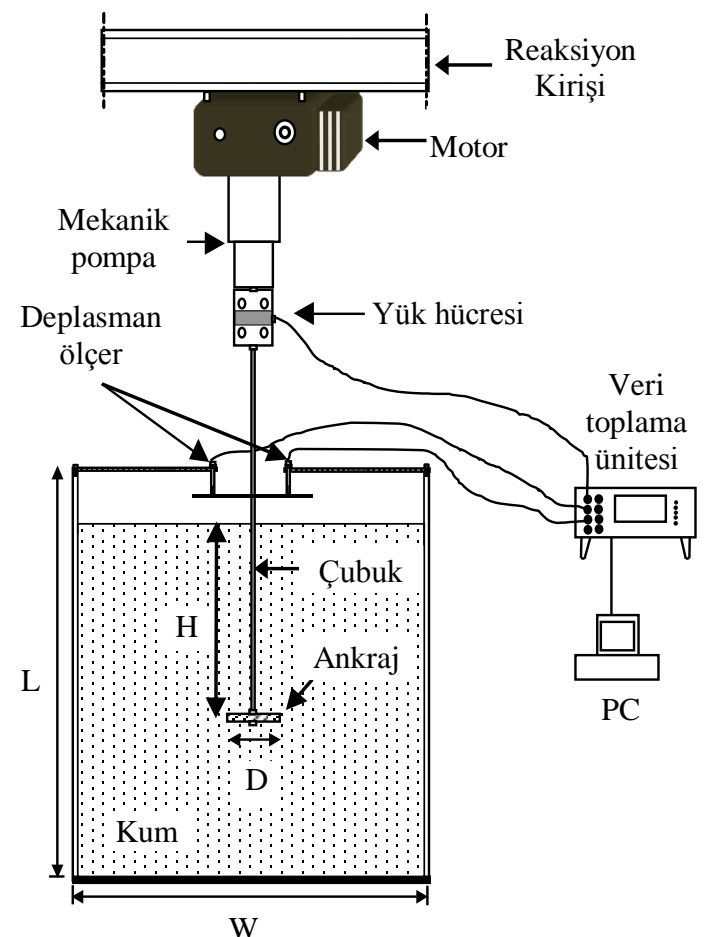

Şekil 4. Deney düzeneği ve yükleme sistemi [23] 


\subsubsection{Kum Zeminin Özellikleri}

Deneysel çalışmalarda model ankrajların gömüldüğü kum yatağının oluşturulması için gerekli kum zemini numuneleri Ceyhan Nehri yatağından alınmıştır. Kum zemini numuneleri üzerinde, zemini sinıflandırmaya ve mekanik özelliklerini tespit etmeye yönelik ASTM standartlarına uygun [24-27] laboratuvar deneyleri yapılmıştır. Gerçekleştirilen elek analizi deneyi sonucunda elde edilen granülometri eğrisi Şekil 5'te görüldüğü gibidir. $\mathrm{Bu}$ deneyler sonucunda, Birleştirilmiş Zemin Sınıflandırma Sistemi'ne [28] göre kullanılan kumun zemin sınıfi, kötü derecelenmiş kum (SP) ve dane birim hacim ağırlığ $\gamma_{\mathrm{s}}=27,3 \mathrm{kN} / \mathrm{m}^{3}$ olarak bulunmuştur. Kum için \%35, \%65 ve \%85 olmak üzere üç farklı rölatif sıkılık $\left(D_{\mathrm{r}}\right)$ seçilmiştir. Üç farklı rölatif sıkılık için kuru birim hacim ağırlıkları sırasıyla $\gamma_{\mathrm{k}}=16,4 \mathrm{kN} / \mathrm{m}^{3}, \gamma_{\mathrm{k}}=17,2 \mathrm{kN} / \mathrm{m}^{3}$ ve $\gamma_{\mathrm{k}}=17,7 \mathrm{kN} / \mathrm{m}^{3}$ olarak hesaplanmıştır.

Kum zeminin kayma mukavemeti parametrelerini tespit etmek için ASTM [29] standardına göre kesme kutusu deneyleri yapılmış ve içsel sürtünme açısı değerleri $\% 35, \% 65$ ve $\% 85$ rölatif sıkılık değerleri için sırasıyla $\varphi=36^{\circ}, \varphi=39^{\circ}$ ve $\varphi=42^{\circ}$ olarak bulunmuştur. Her üç sıkılık için kohezyon değeri sifirdır $(\mathrm{c}=0)$. Kum zemin üzerinde yapılan deneylere ait sonuçlar Çizelge 1'de özetlenmiştir.

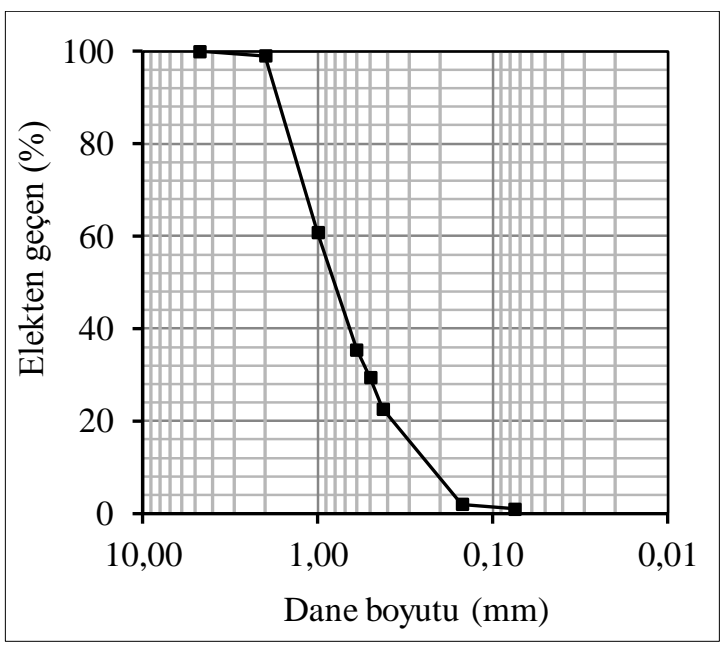

Şekil 5. Kum zemine ait granülometri eğrisi [23]
Çizelge 1. Kum zeminin özellikleri [23]

\begin{tabular}{|l|c|c|c|}
\hline Parametre Adı & Simge & Birim & Değeri \\
\hline $\begin{array}{l}\text { Dane birim hacim } \\
\text { ağırlığı }\end{array}$ & $\gamma_{\mathrm{s}}$ & $\mathrm{kN} / \mathrm{m}^{3}$ & 27,3 \\
\hline $\begin{array}{l}\text { Maksimum kuru } \\
\text { birim hacim ağırlığı }\end{array}$ & $\gamma_{\mathrm{kmax}}$ & $\mathrm{kN} / \mathrm{m}^{3}$ & 18,20 \\
\hline $\begin{array}{l}\text { Minimum kuru } \\
\text { birim hacim ağırlığı }\end{array}$ & $\gamma_{\mathrm{kmin}}$ & $\mathrm{kN} / \mathrm{m}^{3}$ & 15,52 \\
\hline Kaba kum yüzdesi & - & $\%$ & 2 \\
\hline Orta kum yüzdesi & - & $\%$ & 33 \\
\hline İnce kum yüzdesi & - & $\%$ & 64 \\
\hline Efektif çap & $\mathrm{D}_{10}$ & $\mathrm{~mm}$ & 0,3 \\
\hline $\begin{array}{l}\text { Üniformluk } \\
\text { Katsayısı }\end{array}$ & $\mathrm{C}_{\mathrm{u}}$ & $\mathrm{mm}$ & 3,0 \\
\hline Süreklilik Katsayısı & $\mathrm{C}_{\mathrm{r}}$ & $\mathrm{mm}$ & 0,27 \\
\hline Sinıflandırma & - & - & $\mathrm{SP}$ \\
\hline
\end{tabular}

\subsubsection{Deneysel Çalışmanın Gerçekleştirilmesi}

Deney tankına bir tabaka zemin yerleştirilmiş onun yüzeyine model ankraj oturtulmuştur. Bir tabaka zeminin yüksekliği $50 \mathrm{~mm}$ 'dir. Model ankraj deney tankının tam ortasına gelecek şekilde konumlandırılmıştır. Daha sonra model ankraj üzerine tabakalar halinde istenilen gömülme derinliğine kadar kum zemin yerleştirilmiştir. Kum zemin $\% 35, \% 65$ ve $\% 85$ olmak üzere üç farklı sıkılıkta yerleştirilmiştir. Bu üç sıkılıktaki kumun kuru birim hacim ağırlıkları sırasıyla $\gamma_{\mathrm{k}}=16,4$ $\mathrm{kN} / \mathrm{m}^{3} \quad \gamma_{\mathrm{k}}=17,2 \quad \mathrm{kN} / \mathrm{m}^{3} \quad \gamma_{\mathrm{k}}=17,4 \quad \mathrm{kN} / \mathrm{m}^{3}$ olarak hesaplanmıştır. Kum zemin tabakalar halinde sıkıştırılıp yerleştirilirken dinamik yöntem kullanılmıştır. İstenilen sıkılığı deney koşullarında sağlamak amaciyla, her bir tabaka için gerekli olan kum ağırlığı önceden hesaplanarak, kontrollü bir şekilde sıkıştırma işlemi yapılmıştır. Her bir tabakanın yerleştirilme işlemi tamamlandıktan sonra yüzeyinin düzgün olup olmadığı su terazisi yardımıyla kontrol edilirken aynı zamanda tabaka yüksekliğinin de $50 \mathrm{~mm}$ olmasına dikkat edilmiştir. Model ankraj plakasının ve bağlandığı rijit çubuğun yüzeye dik olmasına dikkat edilerek 
eksantrisite oluşumu engellenmeye çalışılmıştır. Deneylerde çekme yükü, model ankrajın yukarı doğru 2,33 mm/dk'lık sabit bir hızla çekilmesi ile oluşturulmuştur. $\mathrm{Bu}$ işlemler tüm deneyler aynı şekilde uygulanmıştır. Yapılan deneylere ait programın özeti ve deneylerden elde edilen çekme kapasitesi $\left(\mathrm{Q}_{\text {ult }}\right)$ Çizelge 2'de görüldüğü gibidir. Tüm deneyler için çekme kapasitesi $\left(\mathrm{Q}_{\text {ult }}\right)$ deneyler sırasında ölçülen maksimum çekme yükü olarak dikkate alınıştır.

Çizelge 2. Deney programı ve deneylerden elde edilen çekme kapasiteleri

\begin{tabular}{|c|c|c|c|c|c|c|c|}
\hline $\begin{array}{l}\text { Test } \\
\text { Serisi }\end{array}$ & $\begin{array}{l}\text { Test } \\
\text { No }\end{array}$ & $\begin{array}{c}\text { Ankraj } \\
\text { Çap1 } \\
(\mathrm{D}, \mathrm{mm})\end{array}$ & $\begin{array}{l}\text { Çan Açısı } \\
\text { (Derece) }\end{array}$ & $\begin{array}{l}\text { Rölatif } \\
\text { Sik1lık } \\
\left(D_{\mathrm{r}}, \%\right)\end{array}$ & $\begin{array}{c}\text { Gömülme } \\
\text { Oran1 } \\
\text { (H/D) }\end{array}$ & $\begin{array}{c}\text { Ankraj } \\
\text { Tipi }\end{array}$ & $\begin{array}{c}\text { Çekme } \\
\text { Kapasitesi } \\
\left(\mathrm{Q}_{\text {ult }}, \mathrm{N}\right)\end{array}$ \\
\hline \multirow{3}{*}{$\begin{array}{c}\text { Seri } \\
\text { I }\end{array}$} & $1 \mathrm{~A}$ & 50 & $\alpha=0^{\circ}$ & 65 & 2 & Dairesel & 25,11 \\
\hline & $1 \mathrm{~B}$ & 50 & $\alpha=25^{\circ}$ & 65 & 2 & Çan Tipi & 23,05 \\
\hline & $1 \mathrm{C}$ & 50 & $\alpha=35^{\circ}$ & 65 & 2 & Çan Tipi & 20,69 \\
\hline \multirow{3}{*}{$\begin{array}{l}\text { Seri } \\
\text { II }\end{array}$} & $2 \mathrm{~A}$ & 100 & $\alpha=0^{\circ}$ & 65 & 2 & Dairesel & 162,99 \\
\hline & $2 \mathrm{~B}$ & 100 & $\alpha=25^{\circ}$ & 65 & 2 & Çan Tipi & 151,41 \\
\hline & $2 \mathrm{C}$ & 100 & $\alpha=35^{\circ}$ & 65 & 2 & Çan Tipi & 138,67 \\
\hline \multirow{3}{*}{$\begin{array}{l}\text { Seri } \\
\text { III }\end{array}$} & $3 \mathrm{~A}$ & 150 & $\alpha=0^{\circ}$ & 65 & 2 & Dairesel & 447,38 \\
\hline & $3 \mathrm{~B}$ & 150 & $\alpha=25^{\circ}$ & 65 & 2 & Çan Tipi & 400,70 \\
\hline & $3 \mathrm{C}$ & 150 & $\alpha=35^{\circ}$ & 65 & 2 & Çan Tipi & 386,38 \\
\hline \multirow{5}{*}{$\begin{array}{l}\text { Seri } \\
\text { IV }\end{array}$} & $4 \mathrm{~A}$ & 50 & $\alpha=25^{\circ}$ & 65 & 1 & Çan Tipi & 5,30 \\
\hline & $4 \mathrm{~B}$ & 50 & $\alpha=25^{\circ}$ & 65 & 2 & Çan Tipi & 23,05 \\
\hline & $4 \mathrm{C}$ & 50 & $\alpha=25^{\circ}$ & 65 & 3 & Çan Tipi & 63,55 \\
\hline & $4 \mathrm{D}$ & 50 & $\alpha=25^{\circ}$ & 65 & 4 & Çan Tipi & 119,64 \\
\hline & $4 \mathrm{E}$ & 50 & $\alpha=25^{\circ}$ & 65 & 5 & Çan Tipi & 180,05 \\
\hline \multirow{4}{*}{$\begin{array}{l}\text { Seri } \\
\mathrm{V}\end{array}$} & $5 \mathrm{~A}$ & 100 & $\alpha=25^{\circ}$ & 65 & 1 & Çan Tipi & 50,80 \\
\hline & $5 \mathrm{~B}$ & 100 & $\alpha=25^{\circ}$ & 65 & 2 & Çan Tipi & 151,41 \\
\hline & $5 \mathrm{C}$ & 100 & $\alpha=25^{\circ}$ & 65 & 3 & Çan Tipi & 306,36 \\
\hline & $5 \mathrm{D}$ & 100 & $\alpha=25^{\circ}$ & 65 & 4 & Çan Tipi & 653,12 \\
\hline \multirow{3}{*}{$\begin{array}{c}\text { Seri } \\
\text { VI }\end{array}$} & $6 \mathrm{~A}$ & 150 & $\alpha=25^{\circ}$ & 65 & 1 & Çan Tipi & 82,18 \\
\hline & $6 \mathrm{~B}$ & 150 & $\alpha=25^{\circ}$ & 65 & 2 & Çan Tipi & 400,70 \\
\hline & $6 \mathrm{C}$ & 150 & $\alpha=25^{\circ}$ & 65 & 3 & Çan Tipi & 1074,42 \\
\hline \multirow{3}{*}{$\begin{array}{l}\text { Seri } \\
\text { VII }\end{array}$} & $5 \mathrm{~A}$ & 50 & - & 65 & 1 & Helisel & 7,45 \\
\hline & $5 \mathrm{~B}$ & 50 & - & 65 & 2 & Helisel & 26,87 \\
\hline & $5 \mathrm{C}$ & 50 & - & 65 & 3 & Helisel & 71,78 \\
\hline \multirow{3}{*}{$\begin{array}{l}\text { Seri } \\
\text { VIII }\end{array}$} & $6 \mathrm{~A}$ & 100 & $\alpha=35^{\circ}$ & 35 & 3 & Çan Tipi & 213,59 \\
\hline & $6 \mathrm{~B}$ & 100 & $\alpha=35^{\circ}$ & 65 & 3 & Çan Tipi & 276,35 \\
\hline & $6 \mathrm{C}$ & 100 & $\alpha=35^{\circ}$ & 85 & 3 & Çan Tipi & 341,66 \\
\hline
\end{tabular}




\subsection{Sayısal Analizler}

Deneysel çalışmanın sayısal analizini gerçekleştirmek için sonlu elemanlar yöntemi kullanılmıştır. Bu amaçla, PLAXIS 2D bilgisayar programı kullanarak deneysel çalışma modellenmiş ve sayısal analizler gerçekleştirilmiştir. Deney düzeneğinin geometrik modeli, iki boyutlu ve eksenel simetrik olarak oluşturulmuştur. Eksenel simetrik koşullarda, geometrik modelin genişliği $300 \mathrm{~mm}$ yüksekliği ise $600 \mathrm{~mm}$ 'dir. Zemin ortamı 15 düğümlü üçgen elemanlarla modellenmiştir. Deney ortamı sonlu elemanlara ayrılırken, ankraj etrafinda ağ sıklaştırması yapılmıştır. Deneylerde kullanılan helisel ankraj, heliselin ankrajın çapına eşit çaplı dairesel ankraj gibi düşünülüp [31] paket programda mevcut olan "plate eleman" olarak modellenmiştir. Yine benzer şekilde, deneylerde kullanılan çan tipi ankraj, çan tipi ankrajın çapına eşit çaplı dairesel ankraj gibi düşünülüp, plate eleman olarak modellenmiştir. Fakat plate elemana, çan tipi ankrajın açısına eşit bir eğim verilmiştir. Dairesel ve çan tipi ankraja ait PLAXIS 2D bilgisayar programından oluşturulmuş sonlu elemanlar ağı Şekil 6'da sunulmuştur.

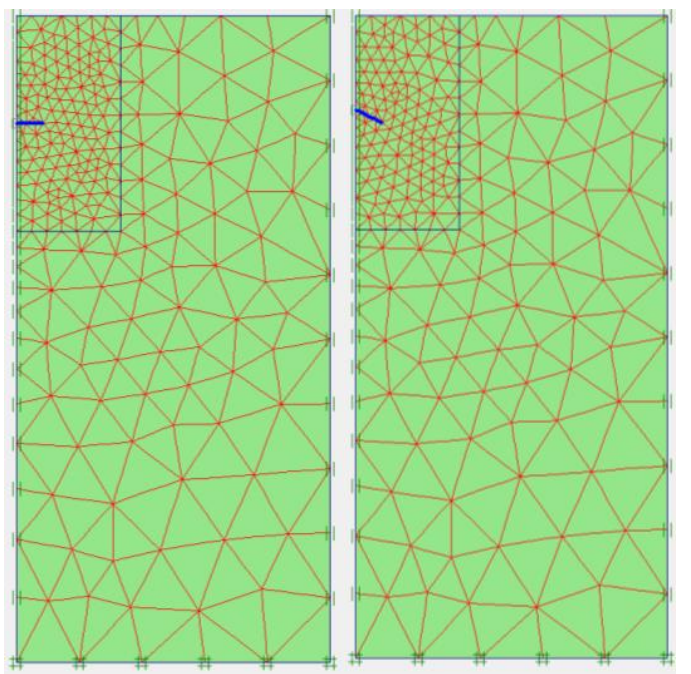

Şekil 6. Dairesel (solda) ve çan tipi ankraja (sağda) ait sonlu elemanlar ağı

Model ankraj, Lineer Elastik malzeme modeli kullanılarak modellenmiş olup, malzeme özellikleri ise, $\quad \mathrm{EA}=5,00 \times 106 \quad \mathrm{kN} / \mathrm{m}$, $\mathrm{EI}=8500 \mathrm{kNm} / \mathrm{m}$ 'dir. Analizlerde kum zeminin davranışı Pekleşen Zemin modeli (Hardening Soil) ile modellenmiştir. Kum zeminin model parametreleri Çizelge 3'te verilmektedir.

Çizelge 3. Kum zemine ait model parametreleri

\begin{tabular}{|l|c|c|c|}
\hline Parametre Adı & Simge & Birim & Değeri \\
\hline Sekant rijitliği & $\mathrm{E}_{50}$ & $\mathrm{kN} / \mathrm{m}^{3}$ & 25000 \\
\hline Başlangıç rijitliği & $\mathrm{E}_{\mathrm{oed}}$ & $\mathrm{kN} / \mathrm{m}^{3}$ & 25000 \\
\hline $\begin{array}{l}\text { Yükleme } \\
\text { boşaltma rijitliği }\end{array}$ & $\mathrm{E}_{\mathrm{ur}}$ & $\mathrm{kN} / \mathrm{m}^{3}$ & 60000 \\
\hline Kuvvet & $\mathrm{m}$ & - & 0,5 \\
\hline $\begin{array}{l}\text { İçsel sürtünme } \\
\text { açısı }\end{array}$ & $\varphi$ & $\left(^{\circ}\right)$ & 38 \\
\hline Dilatasyon açısı & $\psi$ & $\left(^{\circ}\right)$ & 8 \\
\hline Kohezyon & $\mathrm{c}$ & $\mathrm{kN} / \mathrm{m}^{3}$ & 0,1 \\
\hline Poisson oranı & $v$ & - & 0,2 \\
\hline $\begin{array}{l}\text { Sükûnetteki yanal } \\
\text { zemin basıçc } \\
\text { katsayısı }\end{array}$ & $\mathrm{K}_{\mathrm{o}}$ & - & 0,384 \\
\hline Göçme oranı & $\mathrm{R}_{\mathrm{f}}$ & - & 09 \\
\hline Azaltma faktörü & $\mathrm{R}_{\text {inter }}$ & - & 0,9 \\
\hline
\end{tabular}

\section{BULGULAR VE TARTIŞMA}

\section{1. Çan Açısının Etkisi}

Seri I, Seri II ve Seri III deneylerinde çan açısının etkisi incelenmiştir. Bunun için dairesel ankraj $\left(\alpha=0^{\circ}\right)$ ile $25^{\circ}$ ve $30^{\circ}$ çan açısına sahip çan tipi ankrajların çekme davranışları kıyaslanmıştır. 50, 100 ve $150 \mathrm{~mm}$ çaplı ankrajlar kullanılmıştır. Deneyler $\mathrm{H} / \mathrm{D}=2$ (H: ankrajın gömülme derinliği, D: ankrajın çapı) gömülme oranında $\% 65$ rölatif sıkılıkta gerçekleştirilmiştir. Seri I, Seri II ve Seri III deneylerine ait yük (Q) - deplasman oranı (s/D) grafikleri sırası ile Şekil 7, 8 ve 9'da görüldüğü gibidir. Deplasman oranı yüzde cinsindendir. "s" deplasman miktarı "D" ankraj çapıdır. 


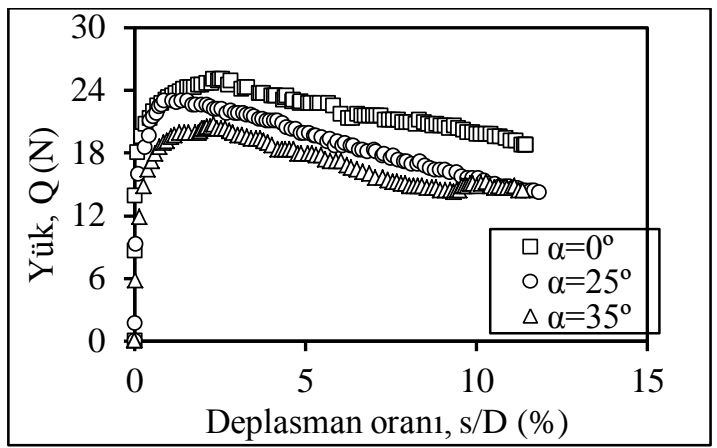

Şekil 7. Seri I deneylerine ait yük-deplasman grafiği $(\mathrm{D}=50 \mathrm{~mm})$

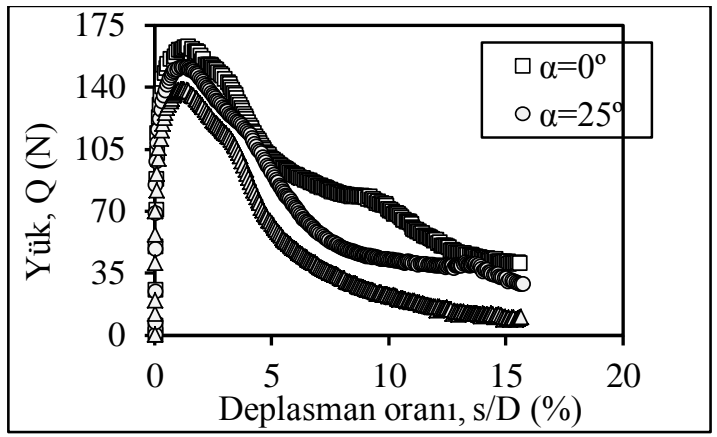

Şekil 8. Seri II deneylerine ait yük-deplasman grafiği $(\mathrm{D}=100 \mathrm{~mm})$

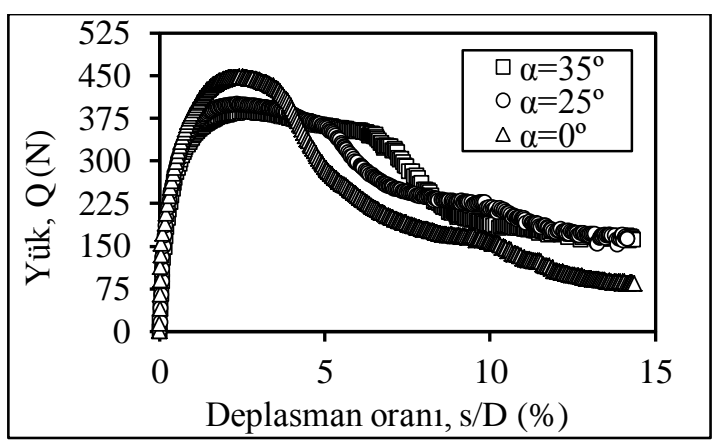

Şekil 9. Seri III deneylerine ait yük-deplasman grafiği $(\mathrm{D}=150 \mathrm{~mm})$

Şekil 7, 8 ve 9 incelendiğinde ankraj açısı arttıkça çekme kapasitesi ( $\left.\mathrm{Q}_{\text {ult }}\right)$ düşmektedir. Fakat bu azalma az miktardır.

\subsection{Gömülme Derinliğinin Etkisi}

Seri IV, Seri V ve Seri VI deneylerinde çan tipi ankrajın Seri VII deneylerinde helisel ankrajın farklı gömülme derinliklerindeki cekme davranışları araştırılmıştır. Bu deney serilerinde 50,100 ve $150 \mathrm{~mm}$ çaplı çan tipi ankrajlar, $50 \mathrm{~mm}$ çaplı helisel ankrajlar kullanılmıştır. Çan tipi ankrajların çan açısı $\alpha=25^{\circ}$ 'dir. Deneyler $\% 65$ rölatif sıkılıkta gerçekleştirilmiştir. Seri IV, Seri V, Seri VI, Seri VII deneylerine ait yük - deplasman oranı grafikleri surası ile Şekil 10-13'te gösterilmiştir.

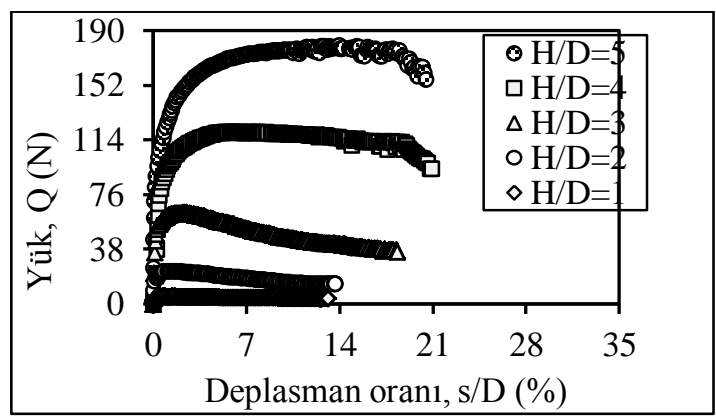

Şekil 10. Seri IV deneylerine ait yük-deplasman grafiği $(\mathrm{D}=50 \mathrm{~mm}$, çan tipi)

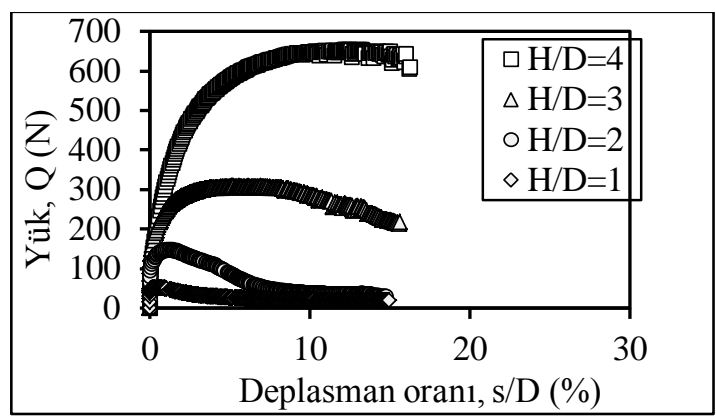

Şekil 11. Seri V deneylerine ait yük-deplasman grafiği ( $\mathrm{D}=100 \mathrm{~mm}$, çan tipi)

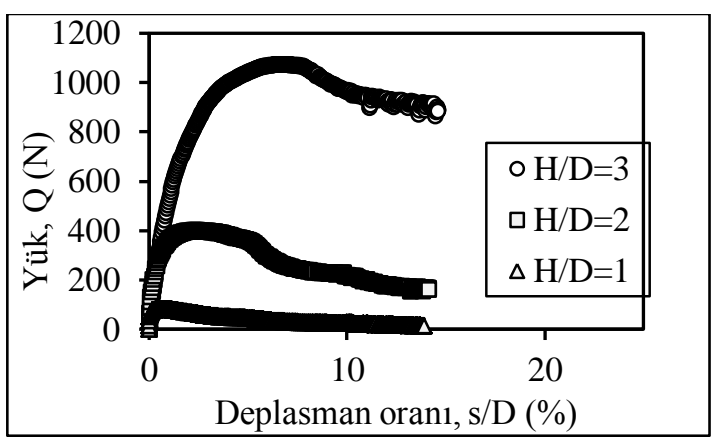

Şekil 12. Seri VI deneylerine ait yük-deplasman grafiği ( $\mathrm{D}=150 \mathrm{~mm}$, çan tipi) 


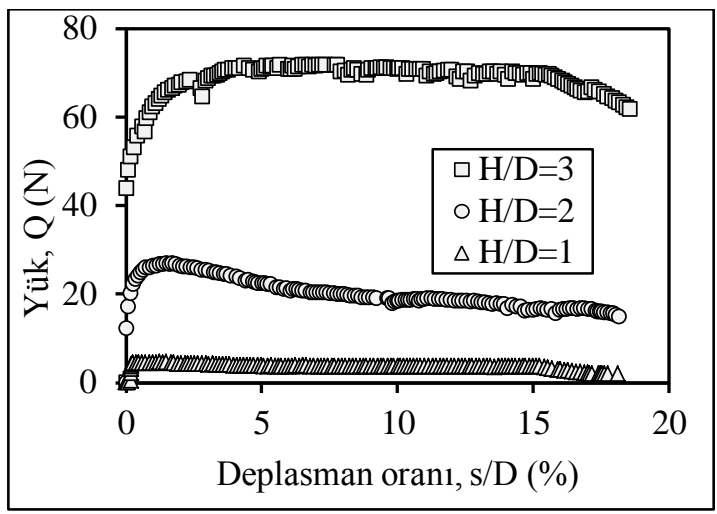

Şekil 13. Seri VII deneylerine ait yük-deplasman grafiği $(\mathrm{D}=50 \mathrm{~mm}$, helisel)

Şekil 10, 11, 12 ve 13 incelendiğinde gömülme derinliği arttıkça çekme kapasitesinin $\left(\mathrm{Q}_{\text {ult }}\right)$ arttığ görülmektedir.

\subsection{Rölatif Sıkılığın Etkisi}

Seri VIII deneyleri rölatif sıklığın çekme davranışına etkisini incelemek için gerçekleştirilmiştir. Deneylerde $\alpha=35^{\circ}$ ankraj açısına sahip $100 \mathrm{~mm}$ çapında çan tipi ankrajlar için yapılmıştır. Gömülme derinliği ise $\mathrm{H} / \mathrm{D}=3$ 'tür. Seri VIII deneylerine ait yük - deplasman oranı grafiği Şekil 14'te sunulmuştur.

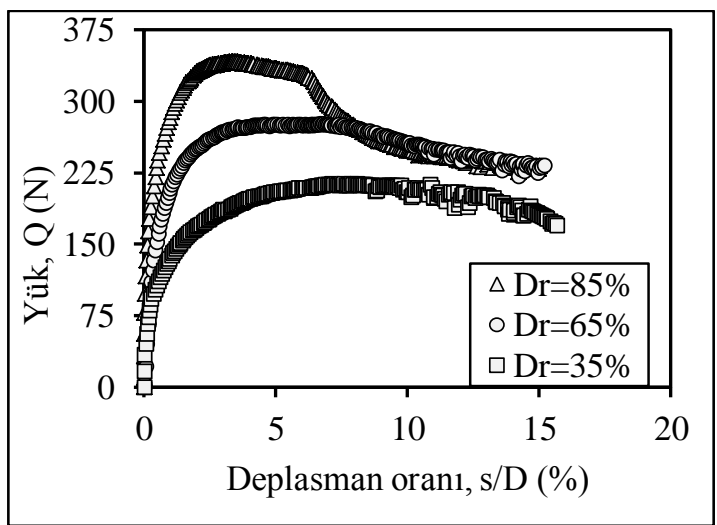

Şekil 14. Seri VIII deneylerine ait yük-deplasman grafiği ( $\mathrm{D}=100 \mathrm{~mm}$, çan tipi)

Şekil 14'te görüldüğü gibi rölatif sıklık arttıkça çekme kapasitesi $\left(\mathrm{Q}_{\mathrm{ult}}\right)$ artmaktadır.

\subsection{Sayısal Analizler ve Kopma Faktörü}

Deneysel çalışmaları modellemek için PLAXIS 2D paket programı kullanılmıştır. Örnek olarak 1A ve 1B deneyleri sonucunda elde edilen yük deplasman oranı grafiği ile bu deneylere ait modellerin sayısal analizlerinden elde edilen sonuçlar sırası ile Şekil 15 ve 16'da sunulmuştur.

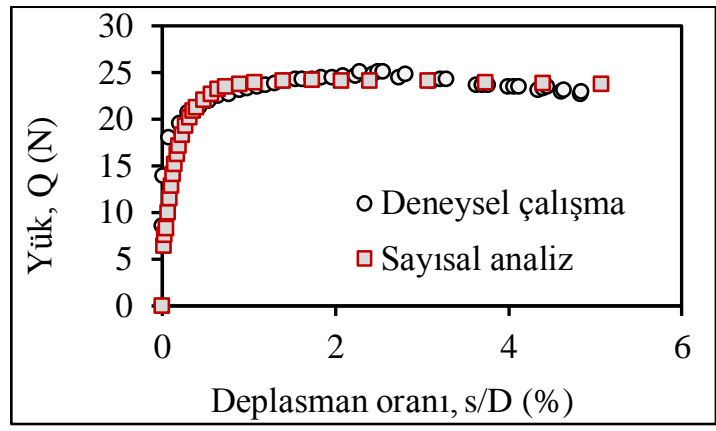

Şekil 15. 1A deneyine ve deneyin sayısal analizine ait yük-deplasman grafiği $(\mathrm{D}=50 \mathrm{~mm}$, dairesel)

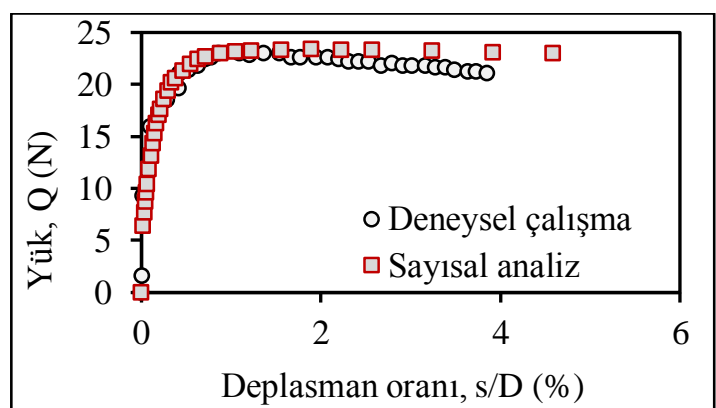

Şekil 16. 1B deneyine ve deneyin sayısal analizine ait yük-deplasman grafiği $(D=50 \mathrm{~mm}$, $\alpha=25^{\circ}$, çan tipi)

Bu kısma kadar deney sonuçları geleneksel yükdeplasman grafikleri şeklinde sunulmuştur. Hem sonuçların daha genel bir şekilde ifade edilmesi hem de deneysel çalışmaları sayısal analizler ve literatürdeki diğer çalışmalar kıyaslamak için, boyutsuz bir parametre olan, kopma faktörü $(\mathrm{Fq})$ kullanılmıştır. Kopma faktörü aşağıdaki gibi tanımlanmaktadır [16].

$$
F q=\frac{\mathrm{Q}_{\mathrm{ult}}}{\gamma \times A \times H}
$$


Bu denklemde kopma faktörü olan " $\mathrm{F}_{\mathrm{q}}$ " hesaplanırken; "Qult" çekme kapasitesi, " $\mathrm{A}$ " en

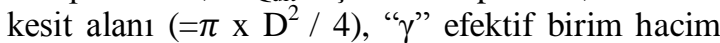
ağırlığı " $H$ " ise ankrajın gömülme derinliği olarak dikkate alınır.

Seri I, II ve III deneylerinde sirası ile 50, 100 ve $150 \mathrm{~mm}$ çaplarındaki ankrajlar \%65 sıkılıktaki kuma $\mathrm{H} / \mathrm{D}=2$ derinliğine gömülmüş ve çan açısının etkisi incelenmiştir. Şekil 17 'de Seri I, II ve III deneyleri ile bu deneylere ait sayısal analizlerin kopma faktörleri görülmektedir. Şekil 17'de görüldüğü gibi ankraj açısı arttıkça kopma faktörü çok az bir miktar azalmaktadır. Şekil 18'de ise Seri I, II ve III deneyleri literatürdeki bir çalışma ile kopma faktörleri cinsinden kıyaslanmıştır. Kıyaslamada deneysel çalışmadaki kopma faktörünün (orta sıkı) literatür çalışmasındaki sıkı ve gevşek durumlar arasında kaldığı ve eğrilerin davranışlarının benzer olduğu görülmüştür.

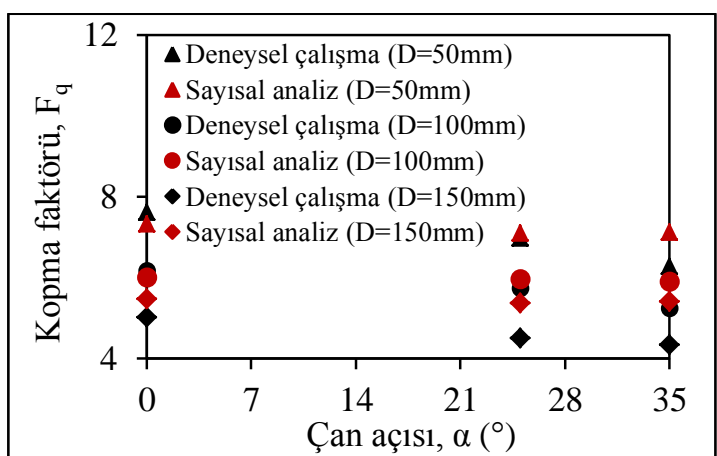

Şekil 17. Seri I, II ve III deneylerine ve bu deneylere ait sayısal analizlere ait kopma faktörleri

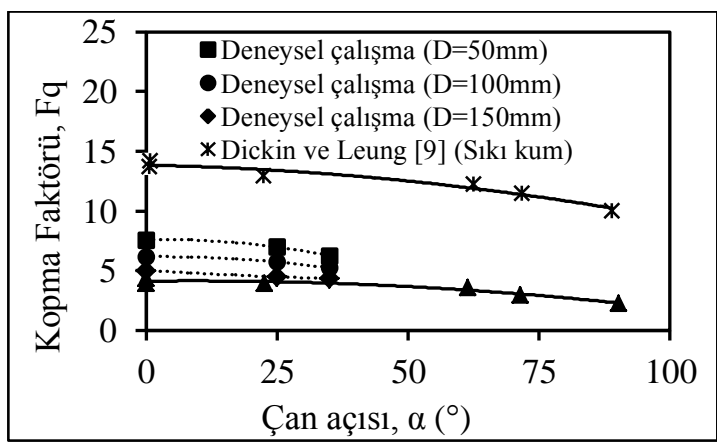

Şekil 18. Seri I, II ve III deneylerinin literatürdeki bir çalışma ile karşılaştırılması
Seri IV, V ve VI deneylerinde çan açısı $25^{\circ}$ olan sırası ile 50,100 ve $150 \mathrm{~mm}$ çaplarında çan tipi ankrajlar \%65 sıkılıktaki kuma farklı derinliklerde gömülmüş ve gömülme oranının etkisi incelenmiştir. Şekil 19, 20 ve 21'de sırası ile Seri IV, V ve VI deneylerine ve bu deneylere ait sayısal analizlere ait kopma faktörleri görülmektedir. Şekil 19, 20 ve 21 'de görüldüğü gibi gömülme oranı arttıkça kopma faktörü değeri de artmaktadır. Ayrıca sayısal analizler ile deneysel çalışmadan elde edilen kopma faktörleri hemen hemen birbirine yakın değerlerdedir.

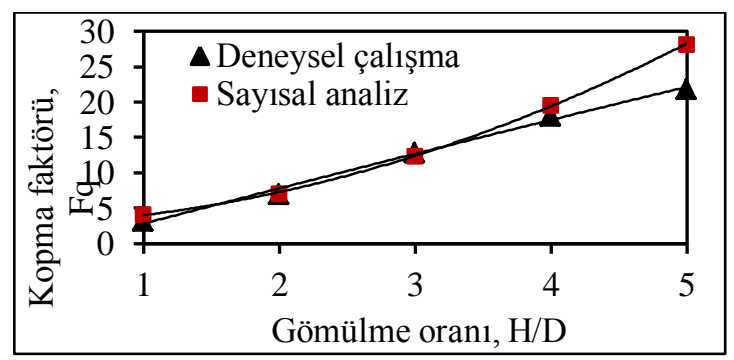

Şekil 19. Seri IV deneyleri ile bu deneylere ait sayısal analizlerin kopma faktörlerinin karşılaştırılması

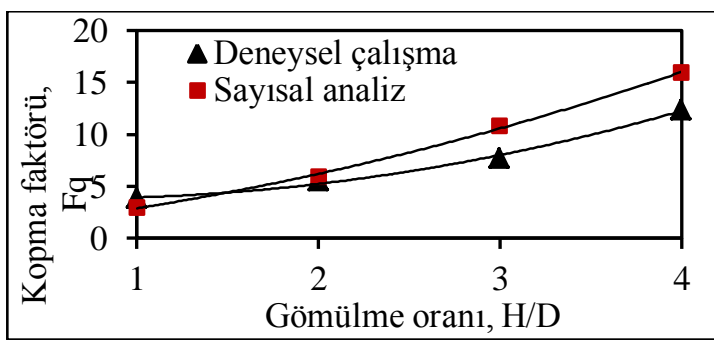

Şekil 20. Seri V deneyleri ile bu deneylere ait sayısal analizlerin kopma faktörlerinin karşılaştırılması

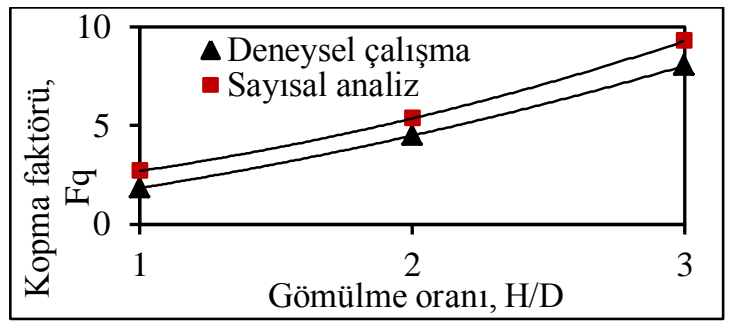

Şekil 21. Seri VI deneyleri ile bu deneylere ait sayısal analizlerin kopma faktörlerinin karşılaştırılması 
Seri VIII deneylerinde rölatif sıkılığın etkisi $H / D=3$ derinliğine gömülmüş çan tipi ankraj için incelenmiştir. $\mathrm{Bu}$ deneylere ait kopma faktörleri hesaplanarak literatürdeki bir çalışma ile karşılaştırılmıştır ve Şekil 22'de görüldüğü gibidir. Şekil 22'de görüldüğü gibi deneysel çalışmadan elde edilen koma faktörleri eğrisi literatürdeki çalışma ile benzer davranışı sergilemektedir.

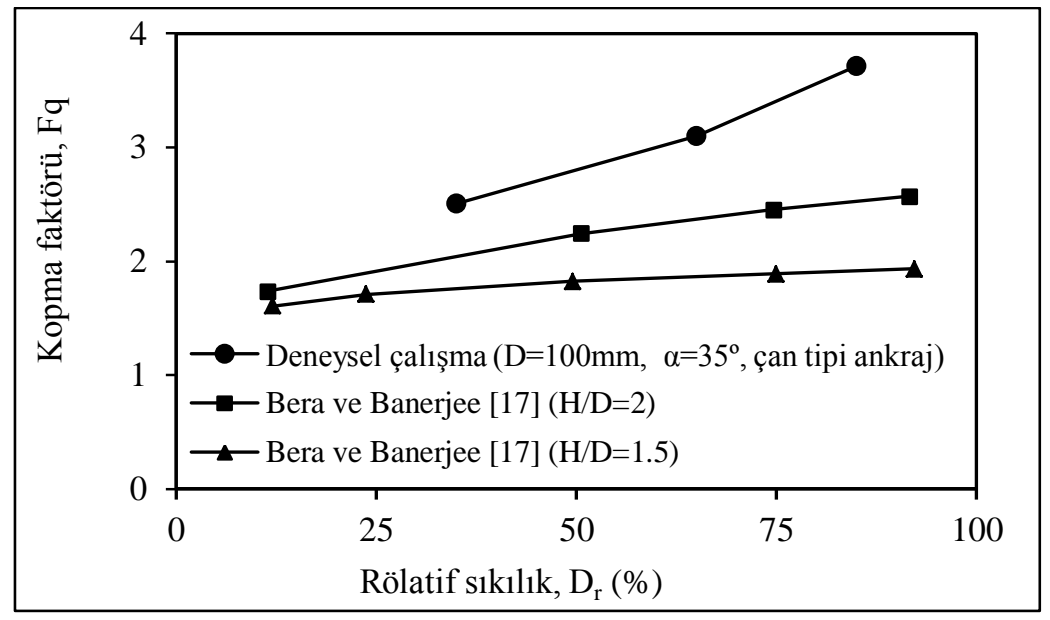

Şekil 22. Seri VIII deneylerinin literatürdeki bir çalışma ile karşılaştırılması

Seri IV, V ve VI (çan tipi) ile Seri VII (helisel ankraj) deneylerine ait kopma faktörleri literatürdeki diğer çalışmalar ile karşılaştırılmıştır ve Şekil 23'de görüldüğü gibidir. Şekil 23'de görüldüğü gibi elde edilen eğrilerin davranışları literatürdeki çalışmalar ile uyum içindedir. Ayrıca aynı çaplı (50 mm) helisel ve çan tipi ankrajların kopma faktörü değerleri birbirine çok yakındır.

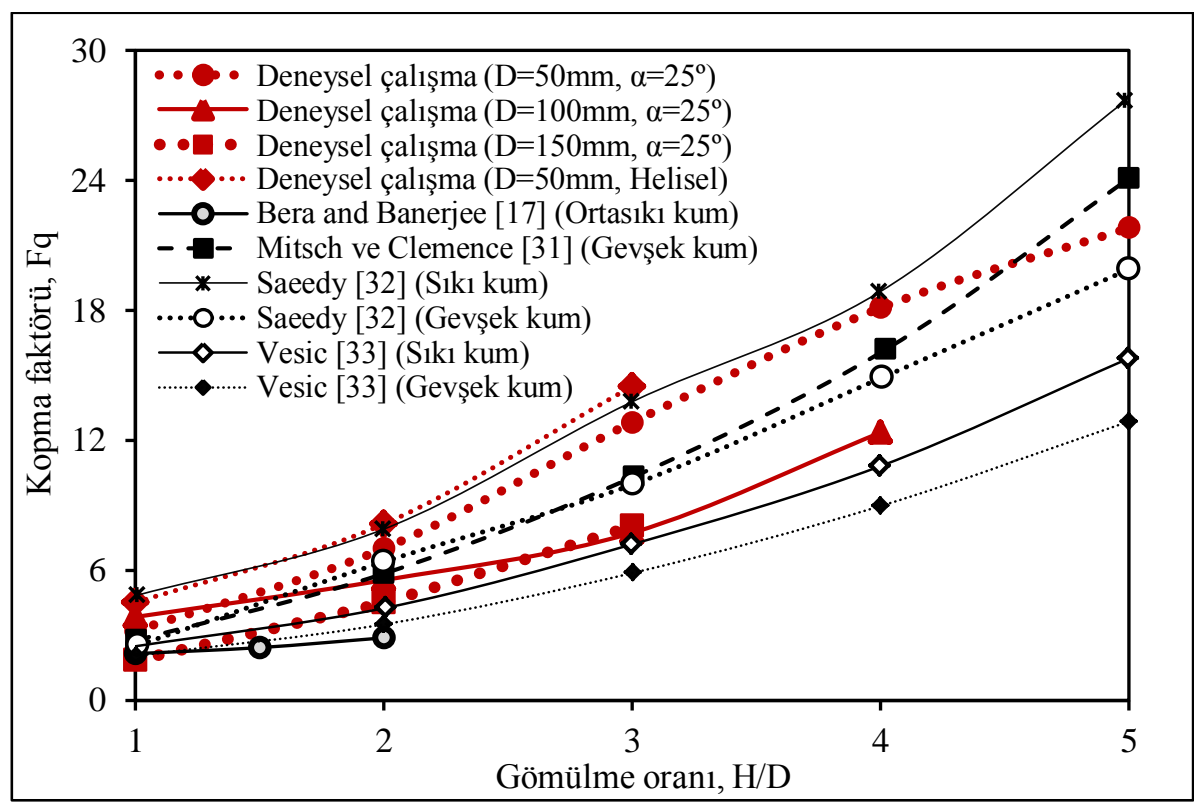

Şekil 23. Seri IV, V ve VI (çan tipi) ile Seri VII (helisel ankraj) deneylerine ait kopma faktörleri literatürdeki diğer çalışmalar ile karşılaştırılması 


\section{SONUÇLAR VE ÖNERILER}

Bu çalışma kapsamında, kum zeminlere gömülü ankraj plakalarının çekme davranışı model deneyler yapılarak ve sayısal analizler gerçekleştirilerek belirlenmiştir. Ankraj plakası olarak çan tipi, dairesel ve helisel ankraj kullanılmıştır. Çan tipi ankrajın çan açısı $\left(0^{\circ}, 25^{\circ}\right.$ ve $\left.35^{\circ}\right)$, temel çap1 $(50,100$ ve $150 \mathrm{~mm})$, gömülme derinliği $(\mathrm{H} / \mathrm{D}=1 \sim 5)$ ve rölatif sıklığ $\left(\mathrm{D}_{\mathrm{r}}=\% 35\right.$, $\% 65$ ve \%85) değiştirilerek bu parametrelerin çekme kapasitesine etkisi incelenmiştir. Kopma faktörü tanımlanarak deneysel çalışmalar sayısal analizler ve literatürdeki çalışmalar ile karşılaştırılmıştır.

Yapılan deneysel çalışmalardan ve sayısal analizlerden aşağıdaki sonuçlar elde edilmiştir:

1. Yapılan çalışmalar ile çan tipi ankrajın eğimli yüzeyinin sahip olduğu açının çekme kapasitesine etkisi araştırılmıştır. Çekme kapasitesi ve kopma faktörü ankraj açısının değişiminden çok fazla etkilenmemektedir. Fakat çekme kapasitesi ve kopma faktörü ankraj açısı arttıkça az bir miktar azalmaktadır.

2. Araştırmalarda, çan tipi ankrajın çekme kapasitesi dairesel ve helisel ankrajınki ile karşılaştırılmıştır. Aynı çaptaki çan tipi, dairesel ve helisel ankrajın çekme kapasitesi ve kopma faktörü değerleri hemen hemen birbirine yakındır.

3. 50,100 ve $150 \mathrm{~mm}$ olmak üzere üç farklı çaptaki çan tipi ankrajın çekme kapasitesi incelenerek ankraj çapının etkisi araştırılmıştır. Çan tipi ankrajın çapı arttıkça çekme kapasitesi artmakta kopma faktörü ise az bir miktar azalmaktadır.

4. Ankrajın kum içine gömülme oranının çekme kapasitesine etkisi araştırmalar kapsamında incelenmiştir. Gömülme oranı arttıkça çekme kapasitesi ve kopma faktörü değerleri artmaktadır.

5. Kumun sahip olduğu rölatif sıkılığın çekme kapasitesine etkisinin olduğu görülmüştür. Rölatif sıkılık arttıkça çekme kapasitesi ve kopma faktörü değerleri artmaktadır.

6. Deneysel çalışmalar sayısal analizler ile modellenmiştir. Böylece sonuçların tutarlılığ kontrol edilmiş ve sonradan yapılabilecek parametrik çalışmalara 1 şı tutacağı düşünülmüştür. Deneysel çalışmalar ile sayısal analizlere ait kopma faktörleri karşılaştırıldığında hemen hemen benzer davranışlar elde edilmiştir. Ayrıca deneysel çalışmalardan elde edilen sonuçlar literatürdeki çalışmalar ile de kıyaslanmıştır. Yapılan çalışmalar literatürdeki çalışmalar ile uyum içerisindedir.

\section{KAYNAKLAR}

1. Majer, P., 1955. Zur Berechnung von zugfundamenten. Osterreichische Bauzeitgschrift (in German) 10(5):85-90.

2. Balla, A., 1961. The Resistance of BreakingOut of Mushroom Foundations for Pylons, Proceedings of the $5^{\text {th }}$ International Conference on Soil Mechanics and Foundation Engineering, Paris, 1, 569-576.

3. Baker, W.H., Kondner, R.L., 1966. Pullout Load Capacity of Circular Earth Anchor Buried in Sand. National Academy of Sciences, Highway Research Board, Report No. 108, $1-10$.

4. Adams, J.I., Hayes, D.C., 1967. The Uplift Capacity of Shallow Foundations, Ontario Hydro Research Quarterly, 19(1), 1-13.

5. Sutherland, H.B., Finlay, T.W., Fadl, M.O., 1982. Uplift Capacity of Embedded Anchors in Sand, In Proceedings of the $3^{\text {rd }}$ International Conference on the Behaviour of Offshore Structures, Cambridge, Mass., 2, 451-463.

6. Das, B. M., Jin, Y. 1987. Uplift Capacity of Model Group Anchors in Sand', In Foundations for Transmission Towers, (ed. B. M. Das), 57-71, New York, ASCE.

7. Murray, E.J., Geddes, J.D., 1987. Uplift Behaviour of Plates in Sand. Journal of Geotechnical Engineering Division, ASCE 113 (3), 202-215.

8. Subbarao C, Mukhopadhyay S, Sinha J, 1988. Geotextiles to Improve Uplift Resistance of Anchors. In: Procedings of the First Indian Geotextiles Conference on Renforced Soil and Geotextiles, Bombay, India, Balkema, Rotterdam, F3-F8. 
9. Dickin, E.A, Leung, C.F, 1990. Performance of Piles With Enlarged Bases Subjected to Uplift Forces. Can Geotech J 27(5), 546-556.

10. Hanna, A. M, Ghaly, A. M, 1994. Ultimate Pull out Resistance of Groups of Vertical Anchors. Can Geotech J 31(5), 673-682.

11. Ilamparuthi, K, Dickin, E. A, 2001. The Influence of Soil Reinforcement on the Uplift Behaviour of Belled Piles Embedded in Sand. Geotext Geomembr 19(1), 1-22.

12. Ilamparuthi, K, Dickin, E. A, 2001. Prediction of the Uplift Response of Model Belled Piles in Geogrid-Cell-Reinforced Sand. Geotext Geomembr 19(1), 89-109.

13. Hamza, AH, 1994. Transmission Line Tower Representation and its Effect on the Tower Surge Response Calculation. Energy Convers Manag 35(12), 1087-1096.

14. Ok, B., 2014. Ankraj Plakalarınının Farklı Zemin Koşullarındaki Çekme Kapasitelerinin İncelenmesi", Yüksek Lisans Tezi, Osmaniye Korkut Ata Üniversitesi, Fen Bilimleri Enstitüsü, Osmaniye.

15. Niroumand H., Kassim K. A., Nazir R., 2010. Uplift Response of Horizontal Strip Anchor Plates in Cohesionless Soil, Electronic Journal of Geotechnical Engineering, 15, 1967-1974.

16. Das, B. M., 1999. Shallow Foundations: Bearing Capacity and Settlement. CRC Press, U.S.A.

17. Bera, A. K., Banerjee, U., 2013. Uplift Capacity of Model Bell Shaped Anchor Embedded in Sand. International Journal of Geotechnical Engineering, 7(1), 84-90.

18. Ravichandran P. T., Ilamparuthi K., Toufeeq M. M., 2008. Investigations on Uplift Behaviour of Plate Anchor in Reinforced Sand Bed, Electronic Journal of Geotechnical Engineering, 13, 1-8.

19. Dickin, E. A., Laman, M., 2007. Uplift Response of Strip Anchors in Cohesionless Soil, Advances in Engineering Software, 38 (8-9), 618-625.

20. Ghaly, A. M., Hanna, A. M., Hanna, M., 1991. Uplift Behaviour of Screw Anchors in Sand, 11: Hydrostatic and Flow Conditions, Journal of Geotechnical Engineering., ASCE, 117 (5), 794-808.
21. Ilamparuthi, K, Dickin, E. A, Muthukrishnaiah K. 2002. Experimental Investigation of the Uplift Capacity of Circular Plate Anchors in Sand. Can Geotech J, 39, 648-664.

22. Krishnaswamy, N. R., Parashar, S.P., 1994. Uplift behaviour of plate anchors with geosynthetics. Geotextiles and Geomembranes 13 (2), 67-89.

23. Sarıcı T., Ok, B., Demir, A., Eroğlu M., An Experimental Study for Uplift Capacity of Anchor Plates Embedded in Sandy Soil, $12^{\text {th }}$ International Congress on Advances in Civil Engineering-ACE 2016, İstanbul, Türkıye, 21-23 Eylül 2016, 1464, 1-9.

24. ASTM D 854-14: Standard Test Methods for Specific Gravity of Soil Soils by Water Pycnometer.

25. ASTM D 4253-00: Standart Test Methods for Maximum Index Density and Unit Weight of Soils Using a Vibratory Table.

26. ASTM D 4254-00: Standart Test Methods for Minimum Index Density and Unit Weight of Soils and Calculation of Relative Density.

27. ASTM C136/C136M-14 Standard Test Method for Sieve Analysis of Fine and Coarse Aggregates.

28. ASTM D2487-11 Standard Practice for Classification of Soils for Engineering Purposes (Unified Soil Classification System).

29. ASTM D 3080-98: Standard Test Methods for Direct Shear Test of Soils Under Consolidated Drained Conditions.

30. Merifield, R. S., 2011. Ultimate Uplift Capacity of Multiplate Helical Type Anchors in Clay, Journal of Geotechnical and Geoenvironmental Engineerıng, 137(7), 704-716.

31. Mitsch, M. P. and Clemence, S. P., 1985. The Uplift Capacity of Helix Anchors in Sand. In Uplift Behavior of Anchor Foundations in Soil, ASCE, 26-47.

32. Saeedy, H. S., 1987. Stability of Circular Vertical Earth Anchors. Canadian Geotechnical Journal, 24(3), 452-456.

33. Vesic, A. S., 1971. Breakout Resistance of Objects Embedded in Ocean Bottom, J. Soil Mechan. Found. Eng., 97, (9), 1183-1205. 
